\title{
Balkanlardaki Geçiş Ekonomilerinde Dış Ticarete Açıklık ve Massetme Kapasitesi Illişkisi (The Relationship Between Openness to Foreign Trade and Absorptive Capacities in Transition Economies in The Balkans)
}

\author{
M. Emre Görgülü iD a \\ ä́lktisadi ve İdari Bilimler Fakültesi, Afyon Kocatepe Üniversitesi, Afyonkarahisar, Türkiye.egorgulu@aku.edu.tr
}

\begin{tabular}{|c|c|}
\hline MAKALE BİLGİSI & ÖZET \\
\hline $\begin{array}{l}\text { Anahtar Kelimeler: } \\
\text { Dış Ticarete Açılılk } \\
\text { Massetme Kapasitesi } \\
\text { Geçiş Ekonomileri }\end{array}$ & $\begin{array}{l}\text { Amaç - Bir ülkenin ihracat ve ithalat değerlerinin, o ülkenin Gayrisafi Yurtiçi Hâsılası'na oranı } \\
\text { olarak ifade edilen dış ticarete açıklık ölçüsü aynı zamanda küreselleşme göstergesi olarak da } \\
\text { kabul edilmektedir. Massetme kapasitesi ise ülkelerin yabancı kaynaklı finansal akımlardan ne } \\
\text { ölçüde faydalanabileceğini ifade eden, o ülkedeki kurumsal ve altyapısal kaliteyi de içeren bir } \\
\text { gelişmişlik seviyesi göstergesi olarak kabul edilmektedir. Bu çalışmada massetme kapasitesinin, } \\
\text { dış ticarete açılık göstergesi üzerindeki etkileri incelenmektedir. }\end{array}$ \\
\hline $\begin{array}{l}\text { Gönderme Tarihi } 28 \text { Aralık } 2018 \\
\text { Revizyon Tarihi } 25 \text { Ocak } 2019 \\
\text { Kabul Tarihi } 10 \text { Şubat } 2019\end{array}$ & $\begin{array}{l}\text { Yöntem - Küreselleşmenin doğal bir sonucu olarak, dış ticarete açıklık birçok ülkede artış } \\
\text { gösterme eğilimindedir. Geçiş Ekonomileri olarak tanımlanan eski Sovyet Blok'u ülkeleri de bu } \\
\text { konuda istisna değildirler. Güney-Doğu Avrupa'da bulunan Balkan Geçiş Ekonomileri, Rusya } \\
\text { hinterlandından uzak olmaları ve henüz Avrupa Birliği üyeliği süreçlerini tamamlamamış } \\
\text { olmaları bakımından diğer eski Sovyet ülkelerinden ayrışmakta ve bu yönleriyle bu çalışmaya } \\
\text { konu olmaktadırlar. Çalışmaya konu olan model panel veri analizi ile ele alınmış olup, } \\
\text { regresyon analizi uygulanmıştır. } \\
\text { Bulgular -Analiz sonuçlarına göre massetme kapasitelerinin o ülkelerde dış ticarete açıklı̆̆ı } \\
\text { olumlu anlamda etkilediği ekonometrik olarak ortaya konulmuştur. Ayrıca, uygulanan diğer } \\
\text { çeşitli ekonometrik testler ile verilerin ve modelin güvenilirliği test edilerek onaylanmıştır. } \\
\text { Tartışma - Böylelikle, henüz geçiş süreçlerini tamamlamamış Balkan Geçiş Ekonomileri için } \\
\text { massetme kapasitelerinin önemi ortaya çıkmış ve massetme kapasitesi artırıcı politikalar } \\
\text { izlemenin gereği vurgulanmıştır. }\end{array}$ \\
\hline
\end{tabular}

\begin{tabular}{|c|c|}
\hline ARTICLE INFO & ABSTRACT \\
\hline $\begin{array}{l}\text { Keywords: } \\
\text { Openness to Foreign Trade } \\
\text { Absorptive Capacity } \\
\text { Transition Economies }\end{array}$ & $\begin{array}{l}\text { Purpose - The openness to foreign trade measure that is expressed as the ratio of sum of a } \\
\text { country's exports and imports to its Gross Domestic Product is considered as an indicator of } \\
\text { globalization at the same time. The absorptive capacity on the other hand, shows to what extend } \\
\text { countries could benefit from foreign financial flows and is considered as an indicator of } \\
\text { development, which also denotes institutional quality along with infrastructural quality. In this } \\
\text { study, the effects of absorptive capacity on the openness to foreign trade are investigated. }\end{array}$ \\
\hline $\begin{array}{l}\text { Received } 28 \text { December } 2018 \\
\text { Revised } 25 \text { January } 2019 \\
\text { Accepted } 10 \text { February } 2019\end{array}$ & $\begin{array}{l}\text { Design/methodology/approach - As a natural outcome of globalization, openness to foreign } \\
\text { trade has shown tendency to grow in many countries. Ex-Soviet Bloc countries defined as the } \\
\text { Transition Economies are no exception in this matter. Balkan Transition Economies located in } \\
\text { South-East Europe are distinguished from other ex-Soviet countries and are subject to this } \\
\text { study in that being far from the Russian hinterland and not being European Union members as } \\
\text { of yet. The model used in the study is handled through panel data analysis and regressed. }\end{array}$ \\
\hline \multirow[t]{2}{*}{ Research Article } & $\begin{array}{l}\text { Findings - It is econometrically revealed that absorptive capacities in countries in question } \\
\text { positively affected openness to foreign trade in those countries. Moreover, applied other various } \\
\text { econometric tests also confirm the integrity and reliability of the data and model. }\end{array}$ \\
\hline & $\begin{array}{l}\text { Discussion - In this way, the importance of absorptive capacities in Transition Economies in the } \\
\text { Balkans who did not yet completed their transition, emerges and the necessity of pursuing } \\
\text { absorptive capacity enhancing policies is emphasized. }\end{array}$ \\
\hline
\end{tabular}




\section{Giriş}

Küreselleşmenin doğal bir sonucu olarak, dış ticarete açıklık birçok ülkede artış gösterme eğilimindedir (The World Bank, 2018). Geçiş Ekonomileri olarak tanımlanan (UN, 2014)eski Sovyet Blok'u ülkeleri de bu konuda istisna değildirler. Geçiş ekonomisi tanımında yer alan "geçiş" ifadesi ile onların kapalı ekonomiden açık ekonomiye geçiş süreçleri kast edilmektedir. Nedeni yöntem kısmında açıklanmak üzere, bu çalışmada Balkanlarda yer alan geçiş ekonomileri konu edilmiştir.

Bir ülkenin ihracat ve ithalat değerlerinin, o ülkenin Gayrisafi Yurtiçi Hâsılası'na oranı olarak ifade edilen (The World Bank, 2018) dış ticarete açıklık ölçüsü aynı zamanda küreselleşme göstergesi olarak da kabul edilmektedir (Igberaese ve Diania, 2012). Massetme kapasitesi ise ülkelerin yabancı kaynaklı finansal akımlardan ne ölçüde faydalanabileceğini ifade eden, o ülkedeki kurumsal ve altyapısal kaliteyi de içeren bir gelişmişlik seviye göstergesi olarak kabul edilmektedir (Görgülü ve Akçay, 2015; Alfaro, Chanda, KalemliÖzcan ve Sayek, 2004; Alfaro, Chanda, Kalemli-Özcan ve Sayek, 2006). Bu açıdan bakıldığında 1991-1992 dönemi öncesi kapalı ekonomi tecrübesi yaşamış olan geçiş ekonomilerinin, Sovyetlerin dağılmasını takiben küreselleşme bandında kendilerine yer bulmaları ile hem dış ticarete açıklıkları artmış hem de massetme kapasitelerini artırabilmişlerdir. Bu durum 2010 sonrası dönemde kendisini çok daha net bir biçimde ortaya koymaktadır (The World Bank, 2018). Bu sebeple, dış ticarete açıklık ile massetme kapasitesi arasında da bir ilişkinin var olup olmadığı sorusu ön plana çıkmıştır. Buradan hareketle, bu çalışmada massetme kapasitesinin, dış ticarete açıklık göstergesi üzerindeki etkileri panel veri seti kullanılarak yapılan regresyon analizinde incelenmiştir.

Çalışmanın ikinci bölümde kavramsal altyapı başlığı altında önce dış ticarete açıklık kavramı üzerinde durulmakta, ardından dış ticarete açıklık ile ilgili literatüre değinilmekte, sonrasında ise massetme kapasitesi kavramının çerçevesi çizilerek ilgili literatür sunulmaktadır. Çalışmanın analiz bölümünün ilk kısmında veri seti ve yöntem üzerinde durulurken, bulgular kısmında analiz bulguları değerlendirilmiştir. Ayrıca yine bu bölümde analizdeki değişkenlerin tanımlayıcı istatistiklerine ve diğer birçok çeşitli ekonometrik ölçümlerine yer verilerek veri setinin sağlamlığı test edilmiştir. Modele uygulanan regresyon analizinin ardından, değerlendirilen bulgular, son bölümde sonuç ve tartışma kısmında tekrar ele alınarak çalışmanın politika çıkarımları kısmı tamamlanmıştır.

\section{Kavramsal Altyap1}

Dış ticarete açıklık bir ülke için belli bir dönemde o ülkenin ithalat ve ihracatının toplamının, yani dış ticaret hacminin, kendi Gayri Safi Yurtiçi Hâsılası (GSYİH)'na oranını şeklinde ifade edilmektedir (The World Bank, 2018). Matematiksel olarak da anlaşılabileceği gibi aslında bu ölçü dış ticarete açıklıktan ziyade dış ticaretin GSYİH içindeki önemini vurgulamaktadır. Bundan dolayı söz konusu ölçü kalabalık nüfusa sahip büyük ülkelerde nispeten daha düşük çıkarken, küçük ülkelerde yüksek çıkmaktadır. Ayrıca örnekleme konu olan ülkeler Sovyet rejiminin dağılmasını takiben Balkanlar'da yaşanan savaş döneminin olumsuzluklarını da tecrübe ettiklerinden, bu dönemin hemen akabinde yavaş yavaş etkin bir serbest piyasa ekonomisine geçiş sürecinde özellikle 2000'lerin başında aşırı dışa bağımlılık yaşamışlardır. Bu durum ihtiyaç duydukları ürünleri o dönemin koşulları göz önüne bulundurulduğunda üretmek yerine ithal etmek zorunda kalmalarından ortaya çıkmaktadır. Dahası örnekleme konu olan söz konusu ülkelerde dış ticarete açıklık değeri 1'e yaklaştıkça görülmektedir ki dış ticaretin o ülkelerin GSYİH'sı içindeki payı artmakta yani o ülkelerin ekonomik büyümesi bir açıdan dış ticarete bağımlı hale gelmektedir.Bu durum sadece Balkanlar'daki geçiş ekonomilerini ilgilendiren bir durum olmamakla beraber yukarda değinildiği gibi GSYİH'sı nispeten küçük olan tüm ülkelerde yaşanmaktadır (The World Bank, 2018). Ancak bu çalışmada kullanılan örneklem dikkate alındığında yapısal olarak birbirine benzer durumdaki geçiş ekonomileri kullanıldığından, söz konusu ölçünün herhangi yanıltıcı bir sonuç vermemesi beklenmektedir.

Diğer taraftan massetme kapasitesi ise en basit haliyle her türlü bilgiyi ve yeniliği özümseyebilme ve bunlardan faydalanabilme kabiliyeti şeklinde tanımlanmıştır (Alfaro et al., 2004; Alfaro et al., 2006; Cohen ve Levinthal, 1989; Cohen ve Levinthal, 1990). Cohen ve Levinthal'ın ilk şeklini verdikleri haliyle (1989; 1990) massetme kapasiteleri mikro seviyede bir sistem olup şirketlerin çevrelerinden her türlü bilgiyi içselleştirebilmelerini ifade etmektedir. Ayrıca bu haliyle massetme kapasiteleri bir nevi adaptasyon ve yenilik yayılması süreci olarak ifade edilmektedir (Cohen ve Levinthal, 1989; Cohen ve Levinthal, 1990). 2000'lerden sonra ise küreselleşmenin artan etkileri neticesinde serbestleşen sermaye hareketlerinin bir 
sonucu olarak, massetme kapasiteleri ülkelerin yeni teknolojileri özümseme ve onlardan faydalanabilme kabiliyeti olarak şekillenmeye başlamış olup, ülkelerin finansal gelişmişlik düzeyleri arttıkça bu kabiliyetlerinin de arttığı ortaya atılmıştır (Alfaro et al., 2004; Alfaro et al., 2006).Böylelikle, massetme kapasitelerinin, üretimde teknolojik bilgi yayılma etkileri vasıtasıyla yeni bilgi edinme sürecinde çok önemli bir rolü olduğu bunun da yabancı yatırımların etkinliğini arttırdığı ortaya çıkmıştır. Bu doğrultuda massetme kapasiteleri bir ülkede yer alan uygun düzenlemelerin varlığı, idari yönetimin kalitesi ve ekonomik yapıya bağlı olarak oluşmaktadır (Görgülü ve Akçay, 2015). Güçlü idari yapıya sahip ülkeler ile sağlam piyasalara sahip ülkelerin yüksek massetme kapasiteleri olacak ve bu ülkeler yabancı yatırımlardan olabildiğince faydalanabileceklerdir. Ancak böylesine güçlü idari ve finansal yapılardan yoksun olan ülkeler ise düşük massetme kapasiteleri neticesinde yabancı yatırımlardan yeteri kadar faydalanamayacaklardır (Alfaro et al., 2004; Alfaro et al., 2006).

Massetme kapasiteleri birbirinden farklı çeşitli yollarla ölçümlenmiştir. Blomstrom, Lipsey ve Zejan (1994) bir massetme kapasitesi belirteci olarak teknoloji açığına odaklanmıştır. Li ve Lui (2005) ise teknoloji açığını Amerika Birleşik Devletleri (ABD) GSYİH'sı ile ev sahibi ülke GSYİH'sı arasındaki farkın ev sahibi ülke GSYİH'na oranı şeklinde ölçerek massetme kapasitesini oluşturmuşlardır. Ayrıca Borensztein, Gregorio ve Lee (1998) eğitim görülen yıl sayısını bir massetme kapasitesi göstergesi olarak kabul etmiş böylelikle beşeri sermayenin massetme kapasitesi içindeki rolüne vurgu yapmışlardır. Durham (2004) ise finansal gelişmişliğin bir başka önemli ve güçlü massetme kapasitesi göstergesi olduğunu ileri sürerek, toplam hisse senedi piyasası sermaye oluşumunun GSYİH'na oranını massetme kapasitesinin finansal kalkınma ölçüsü olarak ele almıştır. Özel sektöre kredi piyasası borç verme kapasitesi ise bir başka finansal gelişmişlik göstergesi olarak massetme kapasitesi ölçümünde yer bulmuştur (Hermes ve Lensink, 2003). Durham (2004) ayrıca çeşitli mülkiyet hakkı düzenleme ve yozlaşma endeksleri de kullanarak kurumsal kalitenin de massetme kapasitesi içinde yer bulmasına olanak sağlamıştır (Krogstrup ve Matar, 2005).

Literatürde massetme kapasitelerinin nasıl ölçüleceğine dair bir fikir birliğinin olmaması daha kapsamlı bir ölçüm ihtiyacını doğurmuştur. Var olan bu farklı ölçümleri ortak bir noktada bir araya getirerek kapsamlı bir şekilde yeni bir ölçüm yöntemi ortaya atan Görgülü'ye göre (2015a) massetme kapasitesi analiz bölümünde detaylıca açıklanacağı üzere; özel sektöre sağlanan yurtiçi kredilerin GSYİH'ya oranı (The World Bank, 2018), Gayri Safi Sermaye Oluşumu (GSSO)'nun GSYİH'ya oranı (The World Bank, 2018) ve UNDP tarafından geliştirilen beşeri sermayenin gelişmişliğini gösteren HDI (UNDP, 2018) değerlerinin ağırlıklı ortalamasının 1 ile farkının alınıp, ABD ile olan kişi başı GSYİH farkının, aynı ülke kişi başı GSYİH'na oranı (The World Bank, 2018) ile elde edilen teknoloji açığı (Li ve Lui, 2005) değeri ile negatif olarak çarpımı ile elde edilir. Böylelikle massetme kapasitesi değeri eksi uzayda arttıkça ülkeye olumsuz etkisi artacağından massetme kapasitesi düşecek, sıfıra yaklaştıkça ise massetme kapasitesi artacaktır (Görgülü, 2015b). Bu yöntem ile massetme kapasiteleri ülkelerin teknolojik gelişmişliklerinin yanında, finansal ve beşeri kalitesini de ortaya koyacağından kapsamlı bir ölçüm haline gelmektedir.

Ayrıca, literatürde massetme kapasitelerinin ülkelerin çeşitli kaynaklardan faydalanabilme kabiliyetini ortaya koyduğu çeşitli çalışmalar da mevcuttur. Bunlardan Alfaro et al. (2004) yerel finansal piyasaların kalitesinin artıp daha iyi performans verdikçe, yabancı yatırımların ekonomik büyümeye katkısının arttığını, böylesine kaliteli finansal piyasalardan yoksun ülkelerde ise yabancı yatırımların büyümeyi artırıcı etkileri olmadığını ortaya koymuşlardır. Nguyen, Duysters, Patterson ve Sandler (2009) ise gelişmekte olan ülkelerin sadece yeterli seviyede massetme kapasitesine sahip olduklarında yabancı yatırımlardan fayda sağlayabileceklerini belirtmişlerdir. Adams (2009) ise, Afrika'ya yapılan yabancı yatırımların etkilerinin bu ülkelerdeki massetme kapasitelerine bağlı olduğunu böylece yabancı yatırımların kalkınma için gerekli ancak yeterli olmadığını bunun yanında massetme kapasitelerinin de artan bir önemi olduğunu vurgulamıştır (Görgülü ve Akçay, 2015). Bu çalışmada kullanılan örneklemdeki aynı ülkelerin kullanıldığı bir başka çalışmada ise, söz konusu Balkan ülkelerinin doğrudan yabancı yatırımlardan faydalanmalarına yarayacak yeterli oranda massetme kapasitelerine sahip olmadıkları, ancak bu kapasitelerini artırdıkları takdirde doğrudan yabancı yatırımlardan daha etkili faydalanabilecekleri ortaya konulmuştur (Görgülü, 2015a). Böylelikle massetme kapasiteleri arttıkça doğrudan yabancı yatırımların olumlu etkileri de artacaktır (Görgülü, 2015a: s.33-34). 


\section{Analiz}

Daha önce de ifade edildiği gibi geçiş ekonomileri başlıca eski Sovyet Blok'u ülkelerinden oluşmaktadır (UN, 2014). Ancak, Bağımsız Devletler Topluluğu üyesi olan Kafkaslar ve Orta Asya'daki Türk Devletleri ile eski Sovyet coğrafyasında halen Rusya ile ciddi ticari ilişkileri bulunan ülkeler veya Rusya'nın zorla etki altına aldığı ihtilaflı ülkeler ${ }^{1}$ ve Avrupa Birliği üyelik süreçlerini tamamlamış eski Sovyet ülkeleri ${ }^{2}$ dış ticaret anlamında sırasıyla Rusya ve Avrupa Birliği'nin geniş etkisi altında kalmaktadırlar. Bu nedenle değinilen ülkeler dış ticarete açıklık konusunda yanıltıcı sonuçlar doğurabilirler. Ayrıca, yukarıda bahsi geçen Avrupa Birliği üyesi ülkeler, Birleşmiş Milletler tanımlamasına göre; Avrupa Birliği üyeliğini takiben artık geçiş ekonomisi sıfatını taşımamaktadır (UN, 2014). İşte bu nedenle bahsi geçen ülkeler ile bazı kaynaklarda geçiş ekonomisi olarak tanımlanan (The World Bank, 2010) ancak halen çatışmalara konu olarak, tam anlamıyla egemenlik bütünlügünü sağlayamamış ve tam olarak tanınmamış olan Kosova (Rettman, 2013) bu ortak paydadan çıkarılmıştır. Böylelikle, Güney-Doğu Avrupa'da Rusya hinterlandından uzak ve Avrupa Birliği üyeliğini tamamlamamış Balkan Geçiş Ekonomileri bu çalışmaya konu olmaktadır. Söz konusu ülkeler Arnavutluk, Sırbistan, Karadağ, Bosna-Hersek ve Makedonya olarak sıralanmakta olup çalışmada uygulanan analiz 2003-2017 yılları arasını kapsayan 15 yıllık veri setini kullanmaktadır. Böylelikle her bir değişken için 75'er gözlemden oluşan panel veri elde edilmiş olup, panel veri analizi ile çalışmanın hem çapraz kesit (cross-sectional) hem de zaman serisi (time-series) boyutlarını yakalaması hedeflenmektedir.

\subsection{Yöntem}

Balkanlardaki geçiş ekonomilerinde massetme kapasitesinin, dış ticarete açıklık üzerindeki etkilerini ortaya koymak için kullanılan model aşağıdaki (1) numaralı denklemde gösterildiği gibi olup; panel veri setinin kullanıldığı modele (1) en küçük kareler (OLS) regresyon analizi uygulanmıştır.

$$
\mathrm{OFT}_{\mathrm{it}}=\beta_{0}+\beta_{1} \mathrm{AC}_{\mathrm{it}}++\varepsilon_{\mathrm{it}}(1)
$$

Modelde (1) Openness to Foreign Trade - Dış Ticare Açıklık (OFTit) bağımlı değişkeni, dış ticarete açıklığı ifade etmekte olup; yukarıda açıklandığı üzere bir ülke için belli bir dönemde o ülkenin ithalat (IMit) ve ihracatının ( $\left.X_{i t}\right)$ toplamının, yine ayn ülkenin GSYİH'na oranını ifade etmektedir (The World Bank, 2018) ve şöyle gösterilir:

$$
\mathrm{OFT}_{\mathrm{it}}=\left(\mathrm{X}_{\mathrm{it}}+\mathrm{IM}_{\mathrm{it}}\right) / \mathrm{GSYIH}_{\mathrm{it}}(2)
$$

Modeldeki (1) bağımsız değişken Absorptive Capacity - Massetme Kapasitesi(ACit) ise bir ülkenin belli bir dönemdeki massetme kapasitesini ifade eder.Bu çalışmada, massetme kapasitesi hesaplanırken yukarıda özetlendiği biçimde (Görgülü, 2015a)ilk olarak aşağıda gösterildiği gibi (3) özel sektöre sağlanan yurtiçi kredilerin GSYİH'ya oranı (DCPSit) (The World Bank, 2018), GSSO'nun GSYİH'ya oranı (GCFit) (The World Bank, 2018) ve UNDP tarafından geliştirilen beşeri sermayenin gelişmişliğini gösteren HDI index (HDIit) değerlerinin (UNDP, 2018) yüzde cinsinden toplamlarının ağırlıklı ortalamaları (WAit) alınır. Burada özel sektöre sağlanan yurtiçi krediler ile GSSO'nun ölçüme dâhil edilmesi massetme kapasitesinin finansal kalite boyutunu ele alması, HDI indeksine yer verilmesi ise ölçümün beşeri sermaye kalitesi boyutunu yansitmasını ifade etmektedir.

$$
\mathrm{WA}_{i t}=\left(\mathrm{DCPS}_{\mathrm{it}}+\mathrm{GCF}_{\mathrm{it}}+\mathrm{HDI}_{\mathrm{it}}\right) / 3(3)
$$

Ardından, aşağıda gösterildiği gibi (4) örneklemde yer alan ülkelerin kişi başı GSYİH'nın (GDPPCit) ABD kişi başı GSYİH (USGDPPCt) ile olan farklarının o ülke kişi başı GSYİH'na (GDPPC ${ }_{i t}$ (The World Bank, 2018) bölünmesi ile elde edilen teknoloji açığı (TGit) (Li ve Lui, 2005) ölçüme dâhil edilir ve böylece ülkelerin gelişmişlik düzeyleri ABD ile kıyaslanabilir bir duruma gelir.

$$
\mathrm{TG}_{\mathrm{it}}=\left(\mathrm{GDPPC}_{\mathrm{it}}+\mathrm{USGDPPC}_{\mathrm{t}}\right) / \mathrm{GDPPC}_{\mathrm{it}}(4)
$$

Teknoloji açığı (TGit) söz konusu ülke için gerçekten de bir açık olması durumunda, o ülkeyi ve gelişmesini olumsuz yönde etkileyeceğinden "_" ile çarpılır ve ardından ağırlıklı ortalama (WAit) değerinin 1'den eksiltilmiş hali ile çarpılarak aşağıdaki massetme kapasitesi ölçüsüne ulaşılır (5).

\footnotetext{
1 Azerbaycan, Kazakistan, Kırgızistan, Tacikistan, Türkmenistan, Özbekistan, Ermenistan, Beyaz Rusya, Gürcistan, Moldova, Rusya Federasyonu, Ukrayna (UN, 2014).

2 Bulgaristan, Hırvatistan, Macaristan, Çekya, Estonya, Letonya, Litvanya, Polonya, Romanya, Slovakya, Slovenya (UN, 2014).
} 


$$
\mathrm{AC}_{\mathrm{it}}=(-\mathrm{TG} \mathrm{it}) \cdot\left(1-\mathrm{WA}_{\mathrm{it}}\right)
$$

Böylelikle teknoloji açı̆̆ının olası olumsuz etkilerinin yüksek bir ağırlıklı ortalama değerinin 1'den çıkartılmış hali ile geçersiz kılınması hedeflenmektedir. Yani teorik olarak, ağırlıklı ortalamada elde edilecek tam skor olan 1, 1'den çıkarıldığında massetme kapasitesi 0 değerine ulaşmış olacak, böylelikle teknoloji açığının etkilerini eleyebilecektir. Yani massetme kapasitesi değeri eksi düzlemden 0'a yaklaştıkça ülkedeki massetme kapasitesi seviyesi iyileșecek ve pozitif bir massetme kapasitesi değeri ile bu durumda ülke teorik olarak bir teknoloji açığına değil fazlasına sahip olacağından, ABD'den daha iyi bir massetme kapasitesine sahip olabilecektir. Bu da demektir ki; bir ülkede söz konusu ölçüm değeri arttıkça, o ülkenin massetme kapasitesi artacaktır (Görgülü, 2015a). Bu ölçüm yolu ile massetme kapasiteleri ülkelerin teknolojik gelişmişlik seviyelerini, finansal gelişmişlik düzeyini ve beşeri sermayesinin kalitesini hep birlikte barındırmaktadır.

Analizde kullanılan dış ticarete açıklık bağımlı ve massetme kapasitesi bağımsız değişkenlerine ilişkin tanımlayıcı istatistikler aşağıdaki Tablo-1'de yer almaktadır.

Tablo-1: Tanımlayıcı İstatistikler

\begin{tabular}{|c|c|c|}
\hline & OFT (Dış Ticarete Açıklık) & $\underline{\mathrm{AC} \text { (Massetme Kapasitesi) }}$ \\
\hline Ortalama & 0.920611 & -5.554126 \\
\hline Orta Nokta & 0.878764 & -5.094236 \\
\hline Maksimum & 1.323403 & -1.739512 \\
\hline Minimum & 0.615131 & -12.19656 \\
\hline Std. Sapma & 0.164247 & 2.047984 \\
\hline Skewness & 0.321147 & -0.835756 \\
\hline Kurtosis & 2.232105 & 3.610612 \\
\hline Jarque-Bera & 3.131886 & 9.896242 \\
\hline Anlamlılık & 0.208891 & 0.007097 \\
\hline Gözlem Sayısı & 75 & 75 \\
\hline
\end{tabular}

Buna göre, OFT serisi için ortalama değerin 0.920611 iken orta noktanın 0.878764 , maksimumun 1.323403 ve minimumun 0.615131 olduğu bu serideki standart sapmanın ise 0.164247 olduğu ortaya çıkmaktadır. Yukarıda değinildiği üzere OFT değişkeninin hesaplanma yöntemi nedeniyle nispeten küçük ülkelerde daha yüksek (1'e yakın) değerlere ulaşması ve 0.920611'lik bir ortalamasının olması, çalışmaya konu olan örneklemdeki tüm ülkelerin nispeten GSYİH yönü ile gelişmiş ülkelere göre daha küçük ülkeler olmasından dolayı normal bir sonuçtur. Aynı değerlere AC serisi için bakıldığında, AC serisinin ortalamasının -5.554126, orta noktasının -5.094236, maksimum değerinin -1.739512 ve minimum değerinin -12.19656 olduğu bu serinin standart sapmasının da 2.047984 olduğu anlaşılmaktadır. Serilerin çarpıklık katsayısı (skewness) OFT serisinde 0.321147 ile sıfırdan büyük pozitif bir değer aldığından serinin sağa çarpık olduğu, AC serisinde ise -0.835756 değeri ile sıfırdan küçük negatif bir değer alarak sola çarpık olduğu ortaya çıkmıştır. Tam anlamıyla normal dağılan bir değişkende ise bu değer 0 çıkacağından simetrik bir dağılım olacaktır. Bu yönüyle çarpıklık katsayısı değerlendirildiğinde OFT serisinin sıfıra daha yakın olması boyutu ile AC serisine göre daha normal bir dağılım sergilediği söylenebilir. Ayrıca, serilerin basıklık katsayısı (kurtosis) incelendiğinde OFT serisinde 2.232105 ile basıklık katsayısı sınır değeri kabul edilen 3'ten küçük olarak normale göre daha basık bir seri olduğu, bununla birlikte AC serisinin aynı katsayı değerinin 3.610612 değeri ile 3'ten büyük olarak normalden daha dik ve sivri bir seri olduğu ortaya çıkmıştır. Böylelikle normale göre daha dik ve sivri olan AC serisinin normal dağılımdan daha uzak olduğu, normale göre dik ve sivri olmayan OFT serisinin ise dik ve sivri olmaması yönü ile daha normal bir seri olduğu söylenebilir (Gujurati ve Porter, 2012). Son olarak uygulanan Jarque-Bera testi ile de serilerin normal dağılımları hakkında yorum yapabilmek mümkün olmaktadır. Buna göre; OFT serisi için söz konusu Jarque-Bera değeri sınır değer olan 5.99'un altında 3.131886 seviyesinde gerçekleștiğinden OFT serisinin normal bir dağılıma sahip olduğu, bununla beraber 9.896242'lik değeri ile AC serisinin sınır değer olan 5.99'un üzerinde olması yönü ile normal bir dağılım sergilemediği söylenebilir.

Ayrıca, panel veri analizinde kullanılan seriler için ayrı ayrı uygulanan tanımlayıcı istatistik testleri sonuçları aşağıdaki Tablo-2'de OFTiçin ve Tablo-3'te ACiçin histogram ile de ifade edilmiş, yukarıda değinilen sonuçlar görsel olarak histogram grafiğinde de teyit edilmiştir. 
Tablo-2: OFT Tanımlayıcı İstatistikler

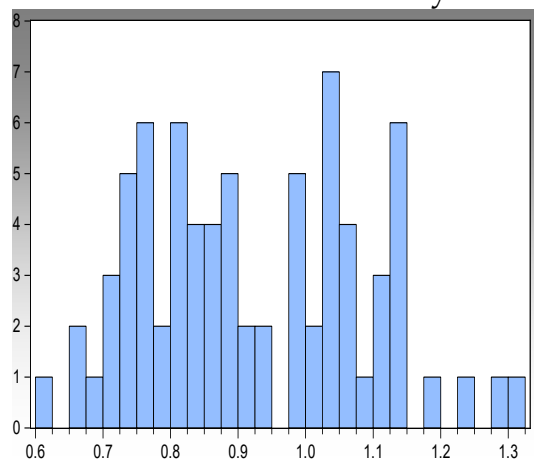

Tablo-3: AC Tanımlayıcı İstatistikler

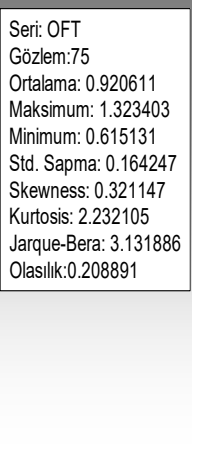

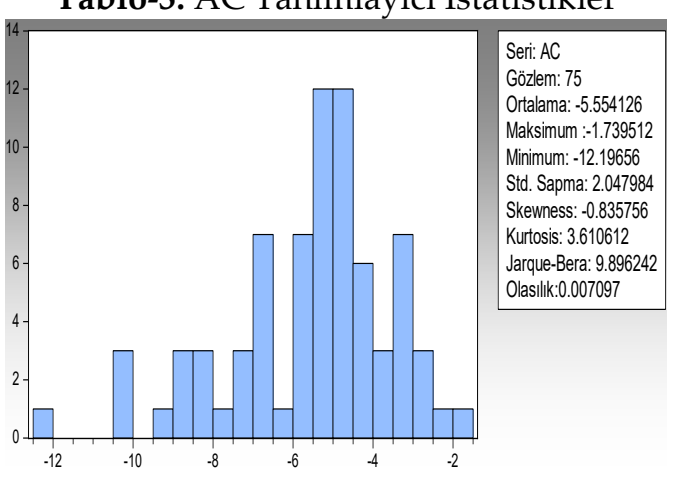

Böylece, tanımlayıcı istatistikler ele alındığında, \%5 anlamlılık düzeyinde OFT değişkeninin normal dağılım sergilediği, AC değişkeninin ise normal dağılım göstermediği ortaya çıkmaktadır.

Değişkenler arasındaki çoklu doğrusal bağlantı (multicollinearity) sorununun olup olmadığına ilişkin olarak Spearman Korelasyon Analizi gerçekleştirilmiş ve analiz sonuçları aşağıdaki Tablo-4'te verilmiştir.

Tablo-4: Spearman Korelasyon Analizi

\begin{tabular}{ccc}
\hline \hline & OFT & AC \\
\cline { 2 - 3 } OFT & 1 & 0.4599146514935988 \\
AC & 0.4599146514935988 & 1 \\
\hline \hline
\end{tabular}

Spearman Korelasyon analizine göre değişkenler arasında [+1,-1] aralığında değer alan korelasyon katsayısının 0'a yaklaştıkça söz konusu değişkenlerin arasındaki ilişkinin azaldığı ve böylece uygulanan model ile analizin güvenilirliğini arttırdığı bilinmektedir. Her iki yönde de 1'e yaklaştıkça ise değişkenler arası ilişki artacak ve bu durum değişkenler arasında çoklu doğrusal bağlantı sorunu doğuracaktır. Spearman Korelasyon analizi sonucuna göre değişkenler arasındaki korelasyonun 0.459914 olduğu ortaya çıkmış, böylelikle değişkenler arasında güçlü bir ilişki tespit edilememiş ve değişkenler arasında çoklu doğrusal bağlantı sorunu olmadığı ortaya çıkmıştır.

Analize konu olan modelin anlamlı sonuçlar verebilmesi için, analizde kullanılan serilerin durağan olması yani birim köke sahip olmamaları gerekmektedir (Gujarati, 2003). Bu doğrultuda, analizde kullanılan serilerin birim köke sahip olmadığını teyit etmek amacıyla LLC birim kök testinin yanı sıra Fisher ADF ve Fisher PP panel birim kök testleri de uygulanmıştır. Aşağıdaki Tablo-5'te verilen birim kök analizi sonuçlarına göre hem sabit hem de hem de trend+sabit etki de serilerin $\% 5$ anlamlılık düzeyinde birim köke sahip olmadığ 1 teyit edilmiştir.

Tablo-5: Birim Kök Analizi

\begin{tabular}{|c|c|c|c|c|c|c|c|c|}
\hline Teknik & & Değişken & İst. & $\mathbf{p}$ & & Değişken & İst. & $\mathbf{p}$ \\
\hline \multirow{2}{*}{ LLC } & \multirow{2}{*}{ Sabit } & OFT & $-6,911$ & 0,000 & Sabit & OFT & $-13,379$ & 0,000 \\
\hline & & $\mathrm{AC}$ & $-6,870$ & 0,000 & $\begin{array}{c}+ \\
\text { Trend }\end{array}$ & AC & $-8,076$ & 0,000 \\
\hline \multirow{2}{*}{ Fisher ADF } & \multirow{2}{*}{ Sabit } & OFT & 55,440 & 0,020 & Sabit & OFT & 56,549 & 0,015 \\
\hline & & $\mathrm{AC}$ & 61,144 & 0,010 & $\begin{array}{c}+ \\
\text { Trend }\end{array}$ & $\mathrm{AC}$ & 67,914 & 0,001 \\
\hline \multirow{2}{*}{ Fisher PP } & \multirow{2}{*}{ Sabit } & OFT & 63,798 & 0,002 & Sabit & OFT & 100,939 & 0,000 \\
\hline & & $\mathrm{AC}$ & 105,216 & 0,000 & $\stackrel{+}{+}$ & AC & 111,650 & 0,000 \\
\hline
\end{tabular}

Tablo 5'teki sonuçlar incelendiğinde, OFT ve AC değişkenlerine ilişkin serilerin sabit ve sabit+trend düzeylerinde birim köke sahip olmadıkları, durağan oldukları yani I(0) oldukları ortaya çıkmıştır. Böylelikle sahte bir regresyon sorununun önüne geçilmiş bulunulmaktadır.

Serilerin doğrusallığının tespitine ilişkin olarak yapılan BDS testi sonucu ise aşağıdaki Tablo-6' da verilmiştir. Tablo 6'ya göre $\% 5$ anlamlılık düzeyi esas alındığında 6. Boyuta kadar yapılan hesaplamalar serilerin 
M.E. Görgülü 11/1 (2019) 1-11

doğrusal dağılım göstermediğini ortaya çıkarmaktadır. Bu durum seriler arasındaki ilişkinin tespiti için regresyon modeli kurulabileceğine işaret etmektedir.

Tablo-6: BDS Doğrusallık Testi

\begin{tabular}{ccccc}
\hline \hline Dimension & BDS Statistic & Std. Error & z-Statistic & Prob. \\
\hline 2 & 0.113991 & 0.009212 & 12.37391 & 0.0000 \\
3 & 0.171819 & 0.014772 & 11.63151 & 0.0000 \\
4 & 0.192176 & 0.017748 & 10.82771 & 0.0000 \\
5 & 0.195807 & 0.018666 & 10.48998 & 0.0000 \\
6 & 0.183071 & 0.018165 & 10.07826 & 0.0000 \\
\hline \hline
\end{tabular}

Uygulanan tüm testlerden elde edilen sonuçlar dikkate alınarak, panelde dirençli tahminciler kullanılarak nihai tahminleme yapılmıştır. Buna göre, dengeli panel veri kullanılarak sabit etkiler modeli esas alınan Modele (1) uygulanan tahminleme sonuçları aşağıdaki Tablo-7' de verilmiştir.

Tablo-7: Tahminleme Sonuçları

\begin{tabular}{|c|c|c|c|c|}
\hline Değişken & Katsayı & Std. Hata & t-Statistic & Prob. \\
\hline $\mathrm{C}$ & 1.123965 & 0.049398 & 22.75322 & 0.0000 \\
\hline $\mathrm{AC}$ & 0.036613 & 0.008351 & 4.384073 & 0.0000 \\
\hline \multicolumn{5}{|c|}{ EffectsSpecification } \\
\hline \multicolumn{5}{|c|}{ Cross-sectionfixed (dummyvariables) } \\
\hline \multicolumn{5}{|c|}{ Periodfixed (dummyvariables) } \\
\hline R-squared & 0.208415 & \multicolumn{2}{|c|}{ Meandependent var } & 0.920611 \\
\hline Adjusted R-squared & 0.197572 & \multicolumn{2}{|c|}{ S.D. dependent var } & 0.164247 \\
\hline S.E. of regression & 0.147130 & \multicolumn{2}{|c|}{ Akaikeinfocriterion } & -0.968695 \\
\hline Sumsquaredresid & 1.580249 & \multicolumn{2}{|c|}{ Schwarzcriterion } & -0.906896 \\
\hline Loglikelihood & 38.32608 & \multicolumn{2}{|c|}{ Hannan-Quinncriter. } & -0.944019 \\
\hline F-statistic & 19.22010 & \multicolumn{2}{|c|}{ Durbin-Watson stat } & 0.538738 \\
\hline Prob(F-statistic) & 0.000038 & & & \\
\hline
\end{tabular}

Regresyon modelinin sonuçlarına göre; AC OFT üzerine \%5 anlamlılık düzeyinde istatistiksel olarak pozitif ve anlamlı şekilde etki etmektedir. AC değişkenindeki 1 birimlik artış OFT değişkenini yaklaşık \%3 oranında artırmaktadır. Modelden elde edilen doğrulayıcı testlere bakıldığında modelin anlamlılık düzeyinin yüksek olduğu ve modeli açıklamada yeterli olduğu ortaya çıkmaktadır. Buna göre OFT bağımsız değişkenini açıklamak için, AC kullanılabilecek bir bağımsız değişkendir.

Bunun yanında, uygulanan analizin doğru ve tutarlı sonuç verebilmesi için analizde kullanılan serilerin değişen varyans ve otokorelasyon testlerine de tabi tutulmaları araştırmanın güvenilirliğini artıracaktır. Çünkü bir tahminleme modelinde otokorelasyona rastlanması sonuçların tutarsız ve sapmış olduğuna işaret ederken, değişen varyansın eksikliği ise sabit varyans varsayımına ve hata terimlerinin varyanslarının tüm kesitler için aynı olması ile kovaryansların sıfıra eşit olması anlamına gelmektedir. Buna göre değişen varyans için uygulanan Breusch-Pagan-Godfrey LM testi ve otokorelasyon için uygulanan Baltagi ve Li(1991) testlerinin sonuçları aşağıdaki Tablo-8' de verilmiştir.

Tablo-8: Değişen Varyans ve Otokorelasyon Testleri

\begin{tabular}{lcc}
\hline \hline & Değişen Varyans & \\
\hline & Test İstatistiği & Anlamlılık düzeyi \\
Breusch-Pagan-GodfreyLMh_fixed & 65,81002 & 0,000000 \\
Ho: Değişen Varyans yoktur & & \\
Hi: Değişen Varyans vardır & & \\
\hline & Otokorelasyon & \\
\hline & Test İstatistiği & Anlamlılık düzeyi \\
Baltagi ve Li (1991) LMp-stat & 0,130783 & 0,707320 \\
Ho: Otokorelasyon yoktur & & \\
H: Otokorelasyon vardır & & \\
\hline \hline
\end{tabular}


Yukarıdaki Tablo-8'de verilen değişen varyans ve otokorelasyon testleri sonuçlarına göre; Breusch-PaganGodfrey LM testi sonucu istatistiksel olarak anlamlı çıkmış böylelikle değişen varyans teyit edilmişken, öte yandan Baltagi ve Li (1991) testi ise istatistiksel olarak anlamlı çıkmadığından modelde otokorelasyon sorunu bulunmadığına işaret etmektedir.

\subsection{Bulgular}

Uygulanan analiz sonuçlarına göre, massetme kapasitelerinin o ülkelerde dış ticarete açıklığı anlamlı ve olumlu olarak etkilediği ekonometrik analiz marifetiyle ortaya konulmuştur. Ayrıca, uygulanan diğer çeşitli ekonometrik testler ile verilerin ve modelin güvenilirliği de test edilerek onaylanmıştır. Buna göre, dış ticarete açıklık değişkeni normal dağılım sergileyen bir seri oluşturmuşken, massetme kapasitesi değişkeni ile elde edilen seri normal dağılıma sahip değildir. Ayrıca söz konusu iki değişken arasında çoklu doğrusal bağlantı sorunu olmadığı anlaşılmıştır. Sonuçların anlamlılı̆̆ noktasında değişkenlerin ikisinin de birim köke sahip olmadığı ve böylece anlamlı sonuçlar ortaya koyabilecekleri belirlenmiştir. Bunun yanında, değişkenlerin değişken varyansa sahip oldukları ve herhangi bir otokorelasyon sorunu barındırmadıkları da ortaya çıkmıştır. Tüm bu bulgular değerlendirildiğinde massetme kapasitelerinin örnekleme konu olan ülkelerde analiz dönemi için dış ticarete açılık değişkeni üzerinde ekonometrik olarak anlamlı ve olumlu bir etkisinin olduğu, massetme kapasitesinin örnekleme konu olan bir ülkede 1 birim artırılmasının söz konusu ülkede dış ticarete açıklığı \%3 oranında arttırdığı sonucu teyit edilmiştir.

\section{Sonuç ve Tartışma}

Bu çalışmada, Balkanlar'da yer alan geçiş ekonomileri olan Arnavutluk, Sırbistan, Karadağ, Bosna-Hersek ve Makedonya'ya 2003-2017 yılları arası uygulanan panel veri analizi sonucunda söz konusu ülkelerde var olan massetme kapasitelerinin bu ülkelerin dış ticarete açıklıklarını ekonometrik olarak anlamlı ve olumlu olarak etkiledikleri ortaya çıkmıştır. Ayrıca, uygulanan diğer ekonometrik testler ile de verilerin tutarlılığı ve güvenilirliği de teyit edilmiştir.

Böylelikle, ekonometrik olarak ulaşılan anlamlı sonuçlar dikkate alındığında, henüz geçiş süreçlerini tamamlamamış Balkan Geçiş Ekonomileri için massetme kapasitelerinin önemi ortaya çıkmış ve massetme kapasitesi artııcı politikalar izlemenin gereği ve önemi vurgulanmıştır. Bu doğrultuda massetme kapasitelerinin geliştirilebilmesi için izlenebilecek politikalar kurumsal kalitenin artırılmasından, iş yapma ortamının kolaylaştırılması ve bürokrasinin yükünün azaltılmasına, finansal piyasaların daha şeffaf ve katı olmasından, mülkiyet haklarının sağlamlaştırılmasına ve beşeri sermayeyi geliştirecek eğitim ve sağlık yatırımlarından yozlaşmayı önleyici önlemlerin kamuya yerleştirilmesine kadar çok çeşitli alanlarda sıralanabilir. Böylece gerçekleştirilecek yapısal reformlar ile ülkelerin daha yüksek bir massetme kapasitesi seviyesine ulaşması mümkün olabilecektir. Genel olarak bu durum da, ülkelerin yabancı yatırımlar gibi çeşitli kaynaklardan daha fazla faydalanabilmelerine olanak sağlayabilecektir (Alfaro et al., 2004; Alfaro et al., 2006). Bu çalışma özelinde ise daha yüksek massetme kapasitelerinin ülkelerin dış ticarete açıklıklarını arttırdığı ortaya çıkmaktadır. Dahası, massetme kapasitelerinin az olduğu durumlarda yabancı yatırımlar gibi dışarıdan gelen kaynakların ekonomik büyüme üzerinde olumsuz etkileri olabileceği de anlaşılmaktadır (Görgülü ve Akçay, 2015). Bundan ötürü, özellikle bu çalışmanın örnekleminde olduğu gibi diş ticaretin GSYİH içindeki payı yüksek olan ülkelerde massetme kapasitelerinin artırılmasının önemi bir kez daha ortaya çıkmaktadır. Örnekleme konu olmuş Balkanlardaki geçiş ekonomilerinin çalkantı ve takip eden geçiş dönemlerinde önceliklerini massetme kapasitesi artırıcı yapısal reformlardan kaydırmış olmaları gerçeği (The World Bank, 2018) bu ülkelerdeki massetme kapasitelerinin diş ticarete açıklıklarını ancak \%3 oranında açıklayabilmesine yol açmıştır. Bu doğrultuda, söz konusu ülkelerde yukarda bahsi geçen yapisal reformların yapılması neticesinde massetme kapasitelerinin artırılabilmesi durumunda dış ticarete açıklıklarının da daha fazla artması öngörülebilir bir beklentidir. 


\section{Kaynakça}

Adams, S. (2009). Can Foreign Direct Investment (FDI) Help to Promote Growth in Africa?African Journal of Business Management, 3(5), 178-183.

Alfaro, L., Chanda, A., Kalemli-Ozcan, S. and Sayek, S. (2004). FDI and Economic Growth: The Role of Local Financial Markets, Journal of International Economics, 64(1), 89-112.

Alfaro, L., Chanda, A., Kalemli-Ozcan, S. and Sayek, S. (2006). How Does Foreign Direct Investment Promote Economic Growth? Exploring the Effects of Financial Markets on Linkages, National Bureau of Economic Research, Working Paper, No. 12522.

Baltagi, B., and Li, Q. (1991). A Joint Test for Serial Correlation and Random Individual Effects, Statistics $\mathcal{E}$ Probability Letters, 11 (3), 277-280.

Blomstrom, M., Lipsey, R. E., and Zejan, M. (1994). What Explains the Growth of Developing Countries? In Baumol, Nelson, and Wolff, (Ed.), Convergence of Productivity: Cross-National Studies and Historical Evidence. Oxford and New York, Oxford University Press, 243-259.

Borensztein, E., Gregorio, J. D., \& Lee, J. W. (1998). How Does Foreign Direct Investment Affect Economic Growth? Journal of International Economics, 45 (1), 115-135.

Cohen, W. M., Levinthal, D. A. (1989). Innovation and Learning: The Two Faces of R\&D. Economic Journal, 99 (397), 569-596.

Cohen, W. M., Levinthal, D. A. (1990). Absorptive Capacity: A New Perspective on Learning and Innovation. Administrative Science Quarterly, 35 (1), 128-152.

Durham, J. B. (2004). Absorptive Capacity and the Effects of Foreign Direct Investment and Equity Foreign Portfolio Investment of Economic Growth. European Economic Review, 48 (2), 285-306.

Gujarati, D. N. (2003). Basic Econometrics, 4th Edition. New York, McGraw-Hill.

Gujarati, D. N., ve Porter, D. C. (2012). Temel ekonometri, (Çev. Ü. Şenesen ve G. G. Şenesen). İstanbul, Literatür Yayıncilik.

Görgülü, M.E. (2015a). The Effects of Foreign Direct Investments on Transition Economies: The Balkans Case. Journal of Economic and Social Studies, 5(2), 23-39.

Görgülü, M.E. (2015b). Görgülü, M.E. (2015a). Foreign Direct Investments: In Pursuit of Happiness. Northern State University 22nd Annual Conference on International Business and Contemporary Issues in BusinessConference Proceedings, (23-38), Rapid City, SD, USA.

Görgülü, M.E.,and Akcay, S. (2015). The Effects of Foreign Direct Investments on Developing Countries. Eurasian Studies, Republic of Turkey Prime Ministry Turkish Cooperation and Coordination Agency, 47(1), 736.

Hermes, N., and Lensink, R. (2003). Foreign Direct Investment, Financial Development and Economic Growth. Journal of Development Studies, 40 (1), 142-63.

Igberaese, F.I., and Diania, E.N.(2012). Trade Openness (Globalization) and Economic Growth Question in Nigeria: An Empirical Evaluation. The Business \& Management Review, 3(1), 138-144.

Krogstrup, S., and Matar, L. (2005). Foreign Direct Investment, Absorptive Capacity and the Arab World, HEI Working Paper No: 02/2005.

Li, X., and Liu, X. (2005). Foreign Direct Investment and Economic Growth: An Increasingly Endogenous Relationship. World Development, 33 (3), 393-407.

Nguyen, H., Duysters G., Patterson, J.H., and Sandler, H. (2009). Foreign Direct Investment Absorptive Capacity Theory, GLOBELICS, 7th International Conference, Dakar, Senegal.

Rettman, A. (2013)Kosovo: EU meeting is 'de facto recognition' by Serbia, https://euobserver.com/foreign/118965 (Erişim Tarihi: 02.12.2018). 
The World Bank.(2010).Kosovo - Country Brief 2010,

http://web.worldbank.org/archive/website01352/WEB/0_CONTE.HTM (Erişim Tarihi: 21.11.2018).

The World Bank. (2018). World Development Indicators 2017. Washington, DC, The World Bank.

UNDP. (2018). Human Development Index, Human Development Report, http://hdr.undp.org/en/data(Erişim Tarihi: 18.12.2018).

UN. (2014).World Economic Situation and Prospects 2014. New York, United Nations. 